\title{
Antifungal Effect of Liposomal $\alpha$-Bisabolol and When Associated with Fluconazole
}

\author{
Camila F. Bezerra ${ }^{1}$, José Geraldo de A. Júnior ${ }^{2}$, Rosilaine de L. Honorato ${ }^{3}$, Antonia Thassya L. dos Santos ${ }^{3}$, \\ Josefa Carolaine P. da Silva ${ }^{3}$, Taís G. da Silva ${ }^{3}$, Thiago S. de Freitas ${ }^{4} \mathbb{D}_{\text {, Thiago Adler T. Vieira }}{ }^{1}$, \\ Maria Clara F. Bezerra ${ }^{5}$, Débora Lima Sales ${ }^{4}$, João Pedro V. Rodrigues ${ }^{2}$, José M. Barbosa Filho ${ }^{6}$ (D), \\ Laisla R. Peixoto ${ }^{6}\left(\mathbb{D}\right.$, Allyson P. Pinheiro ${ }^{3}$, Henrique D. M. Coutinho ${ }^{4, *}$, Maria Flaviana B. Morais-Braga ${ }^{3} \mathbb{D}$ \\ and Teresinha G. da Silva ${ }^{7}$
}

check for

updates

Citation: Bezerra, C.F.; Júnior, J.G.d.A.; Honorato, R.d.L.; Santos, A.T.L.d.; Silva, J.C.P.d.; Silva, T.G.d.; Freitas, T.S.d.; Vieira, T.A.T.; Bezerra, M.C.F.; Lima Sales, D.; et al. Antifungal Effect of Liposomal $\alpha$-Bisabolol and When Associated with Fluconazole. Cosmetics 2021, 8 28. https://doi.org/10.3390/ cosmetics 8020028

Academic Editor: Eliana B. Souto

Received: 27 February 2021

Accepted: 21 March 2021

Published: 2 April 2021

Publisher's Note: MDPI stays neutral with regard to jurisdictional claims in published maps and institutional affiliations.

Copyright: (c) 2021 by the authors. Licensee MDPI, Basel, Switzerland. This article is an open access article distributed under the terms and conditions of the Creative Commons Attribution (CC BY) license (https:/ / creativecommons.org/licenses/by/ $4.0 /)$.
1 Department of Pharmaceutical Sciences, Federal University of Pernambuco-UFPE, Recife 50732-970, Brazil; camilawasidi@gmail.com (C.F.B.); thiago.a.t.vieria@gmail.com (T.A.T.V.)

2 Department of Pharmacy, Federal University of Ceará-UFC, Fortaleza 60455-900, Brazil; junioralencar727@gmail.com (J.G.d.A.J.); jpedroviana@alu.ufc.br (J.P.V.R.)

3 Department of Biological Sciences, Regional University of Cariri-URCA, Crato 63105-010, Brazil; rosilainehonorato@gmail.com (R.d.L.H.); thassyalucas@hotmail.com (A.T.L.d.S.); carol.bio1881@outlook.com (J.C.P.d.S.); taisgusmao96@gmail.com (T.G.d.S.); allysson.pinheiro@urca.br (A.P.P.); flavianamoraisb@yahoo.com.br (M.F.B.M.-B.)

4 Department of Biological Chemistry, Regional University of Cariri-URCA, Crato 63105-010, Brazil; thiagocrato@hotmail.com (T.S.d.F.); debora.lima.sales@gmail.com (D.L.S.)

5 Faculty of Medicine of Juazeiro do Norte-Estácio FMJ, Juazeiro do Norte 63047-045, Brazil; clara-f-b@hotmail.com

6 Department of Pharmacy, Federal University of Paraíba-UFPB, João Pessoa 58051-900, Brazil; jbarbosa@1tf.ufpb.br (J.M.B.F.); laislar@hotmail.com (L.R.P.)

7 Department of Antibiotics, Federal University of Pernambuco-UFPE, Recife 50732-970, Brazil; teresinha100@gmail.com

* Correspondence: hdmcoutinho@gmail.com; Tel.: +55-(88)-3102-1204

Abstract: Fungal pathologies caused by the genus Candida have increased in recent years due to the involvement of immunosuppressed people and the advance of resistance mechanisms acquired by these microorganisms. Liposomes are nanovesicles with lipid bilayers in which they store compounds. $\alpha$-Bisabolol is a sesquiterpene with proven biological activities, and in this work it was tested alone in liposomes and in association with Fluconazole in vitro to evaluate the antifungal potential, Fluconazole optimization, and virulence inhibitory effect in vitro. Antifungal assays were performed against standard strains of Candida albicans, Candida tropicalis, and Candida krusei by microdilution to identify the $\mathrm{IC}_{50}$ values and to obtain the cell viability. The Minimum Fungicidal Concentration (MFC) was performed by subculturing on the solid medium, and at their subinhibitory concentration (Matrix Concentration (MC): 16,384 $\mu \mathrm{g} / \mathrm{mL}$ ) (MC/16), the compounds, both isolated and liposomal, were associated with fluconazole in order to verify the inhibitory effect of this junction. Tests to ascertain changes in morphology were performed in microculture chambers according to MC concentrations. Liposomes were characterized from the vesicle size, polydispersity index, average Zeta potential, and scanning electron microscopy. The $\mathrm{IC}_{50}$ value of the liposomal bisabolol associated with fluconazole (FCZ) was $2.5 \mu \mathrm{g} / \mathrm{mL}$ against all strains tested, revealing a potentiating effect. Liposomal bisabolol was able to potentiate the effect of fluconazole against the CA and CT strains by reducing its concentration and completely inhibiting fungal growth. $\alpha$-Bisabolol in liposomal form inhibited the morphological transition in all strains tested at a concentration of $\mathrm{MC} / 8$. The liposomes were homogeneous, with vesicles with diameters of $203.8 \mathrm{~nm}$ for the liposomal bisabolol and a surface charge potential of $-34.2 \mathrm{mV}$, conferring stability to the nanosystem. Through scanning microscopy, the spherical shapes of the vesicles were observed.

Keywords: liposomes; Candida; fluconazole; dimorphism; nanotechnology 


\section{Introduction}

The high rate of opportunistic fungal infections is of particular concern to patients with some type of immunosuppression. The search for new antifungal drugs is urgent, and it is also a challenging search, mainly due to the cellular and biochemical similarities in eukaryotic cells, making therapeutic management difficult [1].

The main risk factor for Candida colonization is immunosuppression, the use of broadspectrum antibiotic therapy and steroids, mechanical ventilation (MV), neutropenia, diabetes, and others [2].

Among the species of the genus Candida, at least 15 can cause pathologies in humans; however, the largest number of cases are caused by: Candida albicans, Candida glabrata, Candida tropicalis, Candida parapsilosis, and Candida krusei [3-7]. Some yeast species possess a virulence mechanism known as dimorphism; C. albicans, for example, is polymorphic, with two distinct morphological characteristic forms: yeast and filamentous. This ability has been associated with tissue infiltration and biofilm formation critically promoting disease [8-10].

Some compounds from essential oils can be effective against several microorganisms. The class of terpenes is characterized by being lipophilic hydrocarbons composed of isoprenes, which are units of five carbons. The lipo affinity allows a better insertion in the lipid bilayer of the cell membranes. Consequently, terpenoid compounds can generate significant changes in the cellular structures and mitochondrial membrane of different microorganisms [11-13].

$\alpha$-Bisabolol, as well as other sesquiterpenes, is found in oils from plants such as Arnica longifolia, Aster hesperius, and Chrysothamnus nauseosus, which have various biological activities, including anti-inflammatory, antioxidant, and antimicrobial ones [14,15].

Liposomes are spherical vesicles, formed by an internal aqueous core surrounded by one or more concentric lipid bilayer, composed of amphiphilic lipid molecules, such as phospholipids. They present advantages over oral use, also being biodegradable, biocompatible, and nontoxic. They are recognized as being highly versatile for storing a variety of hydrophilic, lipophilic, and amphiphilic character compounds [16-18].

Liposomes biochemically resemble endogenous exosomes [19-22]. They efficiently penetrate the endothelial barrier and deeply reach target cells in most major organs by "passive delivery" of therapeutic drugs with varying charges [22-26].

Combinations of active pharmaceuticals against $C$. albicans may prove to be more useful as therapeutic agents than compounds that are used alone. Therefore, some natural substances are investigated for synergism when applied with azoles, polyenes, or echinocandins that are currently used in the treatment of Candida infection [27].

This study aims to demonstrate the in vitro antifungal activity of Bisabolol isolated in liposomal form and associated with fluconazole against strains of $C$. albicans, C. tropicalis, and C. krusei, and in addition to verify their action on one of the fungal virulence factors, dimorphism. This is the first study that shows the antifungal activity of sesquiterpene bisabolol in a liposomal nanosystem both under isolated action and in association with antifungal fluconazole.

\section{Materials and Methods}

\subsection{Antifungal Testing}

\subsubsection{Strains, Culture Media, and Drugs}

The strains used in the tests were of the standard type provided by the National Institute for Quality in Health (FioCruz, Rio de Janeiro); CA INCQS 40006, CT INCQS 40042, and CK INCQS 40095 were the three species used. For yeast cultivation ( $24 \mathrm{~h}$ at $37^{\circ} \mathrm{C}$ ), the culture media used was Sabouraud Dextrose Agar (SDA, KASVI). After cultivation, a small sample of the colonies was placed in a test tube containing $3 \mathrm{~mL}$ of saline solution $(\mathrm{NaCl} 0.9 \%)$, after which the tube was visually compared to the McFarland 0.5 scale [28]. The second medium was Sabouraud Dextrose Broth (SDB, HIMEDIA), which was used in a doubly concentrated form for the microdilution tests, and the third medium 
was the Potato dextrose Agar (PDA) used in the micromorphology assays. The bisabolol sesquiterpene (93\%) was purchased by the company Sigma Aldrich (St. Louis, MO, USA). For a better dilution of the hydrophobic compound, we used Dimethyl Sulfoxide (DMSO, Merck, Darmstadt, Germany) and the drug fluconazole as an antifungal (Prati donaduzzi), which was dissolved in distilled water. This preparation is in line with Stoppa et al. [29].

\subsubsection{Determination of $\mathrm{IC}_{50}$-Values and Analysis of Cell Viability}

The cultures and treatments were performed as described by Javadpour and collaborators [30]. The readings were performed at $630 \mathrm{~nm}$ using a spectrophotometer (Thermoplate ${ }^{\circledR}$ ), and the data were used to determine the cell viability and calculate the $\mathrm{IC}_{50}$ of each treatment, as previously described [31].

\subsubsection{Determination of the Minimum Fungicidal Concentration (MFC)}

The Minimum Fungicide Concentration was determined as described in the study by Ernst et al. [32], with few modifications, according to Morais-Braga et al. [31]. The Minimum Fungicidal Concentration (CFM) was defined as the lowest concentration in which no growth of fungal colonies was observed.

\subsubsection{Evaluation of the Action-Modifying Effect of Fluconazole}

The antifungal enhancing activity in association with fluconazole was investigated using the method described by Coutinho et al. [33].

\subsubsection{Effect of Natural Products on Fungal Morphology}

To investigate the effects of the treatments on fungal morphology, the development of hyphae was analyzed by optical microscopy in chambers containing sterile slides for the observation of yeasts, as previously described [34,35], with some modifications.

The slides of the strains treated with different concentrations of the compounds were photographed, and the length of the filament extensions (hyphae and pseudohyphae) was determined using the Zen 2.0 software [36].

\subsection{Preparation of the Nanostructured Systems}

The formulation of the liposomes and the entire preparation process that has been followed is described in Barros et al. [37]

\subsection{Physico-Chemical Characterization of Modified Release Systems}

Vesicle Size, Morphology, Polydispersity Index and Average Zeta Potential.

To identify the vesicle size, liposome morphology, polydispersity index, and average Zeta potential, the process described in Júnior et al. [38] was used.

\subsection{Statistical Analysis}

$\mathrm{IC}_{50}$ values were calculated by nonlinear regression from the equations of the calculated curves based on each quadruplicate and were expressed as the arithmetic mean \pm standard error of the mean. The statistical significance was checked by a one-way ANOVA test with Tukey post hoc test.

Fungal growth curves were calculated as the arithmetic mean \pm standard deviation of the quadruplicate mean. The statistical significance between fluconazole (control) and the substances was calculated at each concentration using a two-way ANOVA with Bonferroni post hoc test. Graphpad Prism software, v. 5.0 was used for the statistical analysis.

\section{Results}

\subsection{Growth Inhibition and Action-Modifying Effect of Fluconazole - Cell Viability and IC $_{50}$}

In Table 1, we have the 50\% inhibition concentration of the fungal colony growth $\left(\mathrm{IC}_{50}\right)$ of the products acting alone, both in free and liposomal forms. Additionally, we have the values of the compounds in their subinhibitory concentration, the Matrix Concentration 
(MC) $16,384 \mu \mathrm{g} / \mathrm{mL}$ (MC/16), which is associated with fluconazole. The Minimum Fungicidal Concentration (MFC) value of free bisabolol, liposomal bisabolol, liposome control, and fluconazole corresponded to a concentration $\geq 16,384 \mu \mathrm{g} / \mathrm{mL}$.

Table 1. Values of $\mathrm{IC}_{50}(\mu \mathrm{g} / \mathrm{mL})$ (in the mean \pm standard error of the mean) of the free $\alpha$-bisabolol, $\alpha$-bisabolol in liposomal form, liposomes control, and fluconazole against Candida strains.

\begin{tabular}{cccc}
\hline SUBSTANCE & CA INCQS 40006 & CT INCQS 40042 & CK INCQS 40095 \\
\hline Fluconazole & $55.98 \pm 12.11$ & $1168 \pm 118.25$ & $35.68 \pm 1.74$ \\
\hline Liposome control & $13,512 \pm 1369.41$ & $23,491 \pm 823.49$ & $39,278 \pm 7467.99$ \\
\hline$\alpha$-Bisabolol & $4546 \pm 97.54$ & $105,717 \pm 26,254$ & $4654 \pm 98.50$ \\
\hline$\alpha$-Bisabolol (L) & $3914 \pm 97.58$ & $10,011 \pm 1056.33$ & $2601 \pm 98.44$ \\
\hline
\end{tabular}

Values of $\mathrm{IC}_{50}(\mu \mathrm{g} / \mathrm{mL})$ of free bisabolol, bisabolol in liposomal form, and the controls associated with fluconazole.

\begin{tabular}{cccc}
\hline Substance & CA & CT & CK \\
\hline Fluconazole & $55.98 \pm 12.11$ & $1168 \pm 118.25$ & $35.68 \pm 1.74$ \\
\hline Liposome + FCZ & $788 \pm 142.15$ & $1737 \pm 164.51$ & $61.33 \pm 6.75$ \\
\hline$\alpha$-Bisabolol + FCZ & $1142 \pm 47.4$ & $925 \pm 169.29$ & $37.09 \pm 5.36$ \\
\hline Bisabolol (L) + FCZ & $2.59 \pm 0.07$ & $2.5 \pm 0.01$ & $70.90 \pm 5.43$ \\
\hline
\end{tabular}

(L): liposomal; CA: Candida albicans; CT: Candida tropicalis; CK: Candida krusei INCQS: National Institute for Quality Control in Health. Each result is the geometric mean of four simultaneous experiments.

The concentration values ranged from 2.5 to $105,717 \mu \mathrm{g} / \mathrm{mL}$. $\alpha$-Bisabolol alone and in liposomal form both failed to demonstrate a clinically relevant antifungal activity, presenting an $\mathrm{IC}_{50}$ with high values compared to the control (fluconazole), and reaching the highest value of the test at $105,717 \mu \mathrm{g} / \mathrm{mL}$ against Candida tropicalis (CT).

However, when we observed the values of the concentrations of the compounds associated with fluconazole, a considerable reduction in concentration was noticed, especially for the association between liposomal $\alpha$-bisabolol and fluconazole against Candida albicans and Candida tropicalis, reaching a concentration of $2.5 \mu \mathrm{g} / \mathrm{mL}$. It is worth mentioning the values referring to $\mathrm{CT}$, which present a reduction of the concentration of approximately four thousand-fold when compared to its isolated value, being statistically and clinically relevant.

In Figure 1, observing the cell viability of the fungi shows the action of the compounds (free $\alpha$-bisabolol, in liposomal form, liposomes control, and FCZ) during fungal inhibition against strains of the genus Candida. In the graphs, the performances of the compounds were similar, all demonstrating a low antifungal potential in relation to the control (FCZ) and showing inhibition with very high values (Figure 1A) for CA $8192 \mu \mathrm{g} / \mathrm{mL}$. In Figure $1 \mathrm{~B}$, the compounds did not reach a graphically possible concentration, nor did they against CK $4096 \mu \mathrm{g} / \mathrm{mL}$ (Figure 1C). The liposomes control, being only vesicles without any incorporated drug, did not show an inhibition effect against any strains, as expected.

In Figure 2, we have the results of the cell viability for the following associations: $\alpha$ bisabolol in its free and liposomal forms together with fluconazole. It is worth mentioning that the sesquiterpene in question was used in its subinhibitory concentration (that is, its Matrix Concentration ( $\mathrm{MC}=16,384 \mu \mathrm{g} / \mathrm{mL}$ ) divided by 16 ) so that in this way the natural product could not alone inhibit the yeasts but, in this concentration, potentiate the action of fluconazole. The graphs together with the high $\mathrm{IC}_{50}$ concentrations reveal that the control of liposomes and free bisabolol did not demonstrate a significant antifungal activity even in association with the antifungal. 


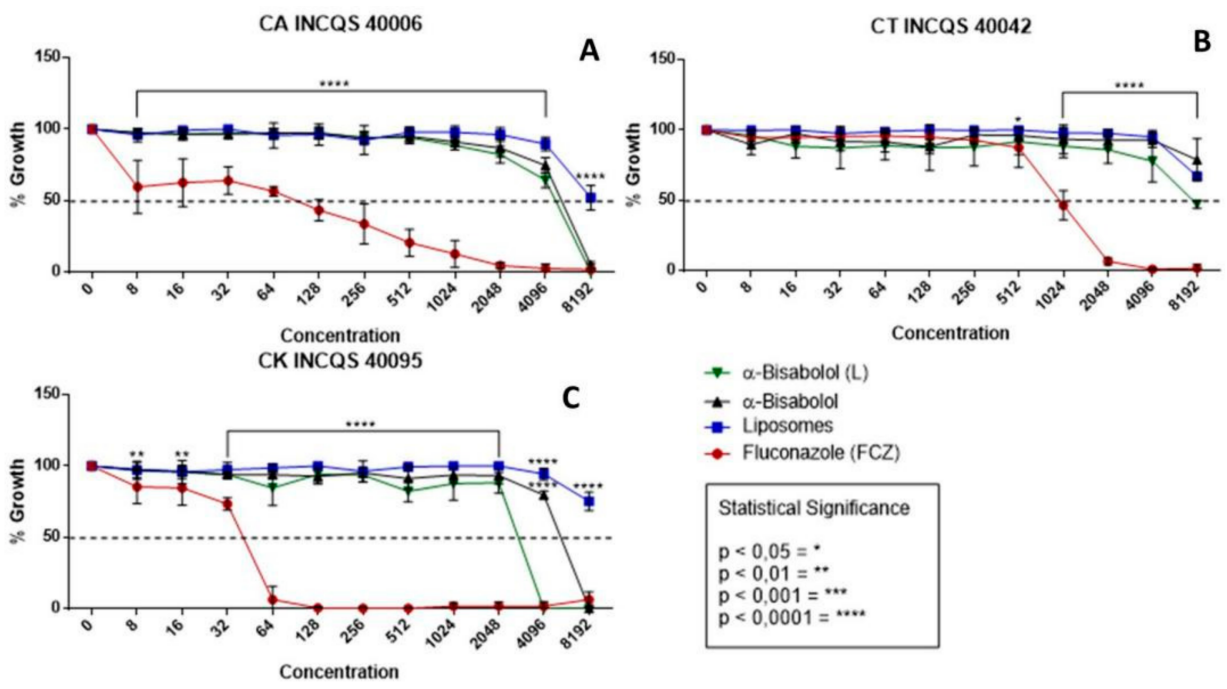

Figure 1. Cell viability curve $(\mu \mathrm{g} / \mathrm{mL})$ of free $\alpha$-bisabolol, $\alpha$-bisabolol in liposomal form, liposomes (control), and isolated fluconazole as control against Candida strains. (L): lipossomal; CA: Candida albicans; CT: Candida tropicalis; CK: Candida krusei INCQS: National Institute for Quality Control in Health.

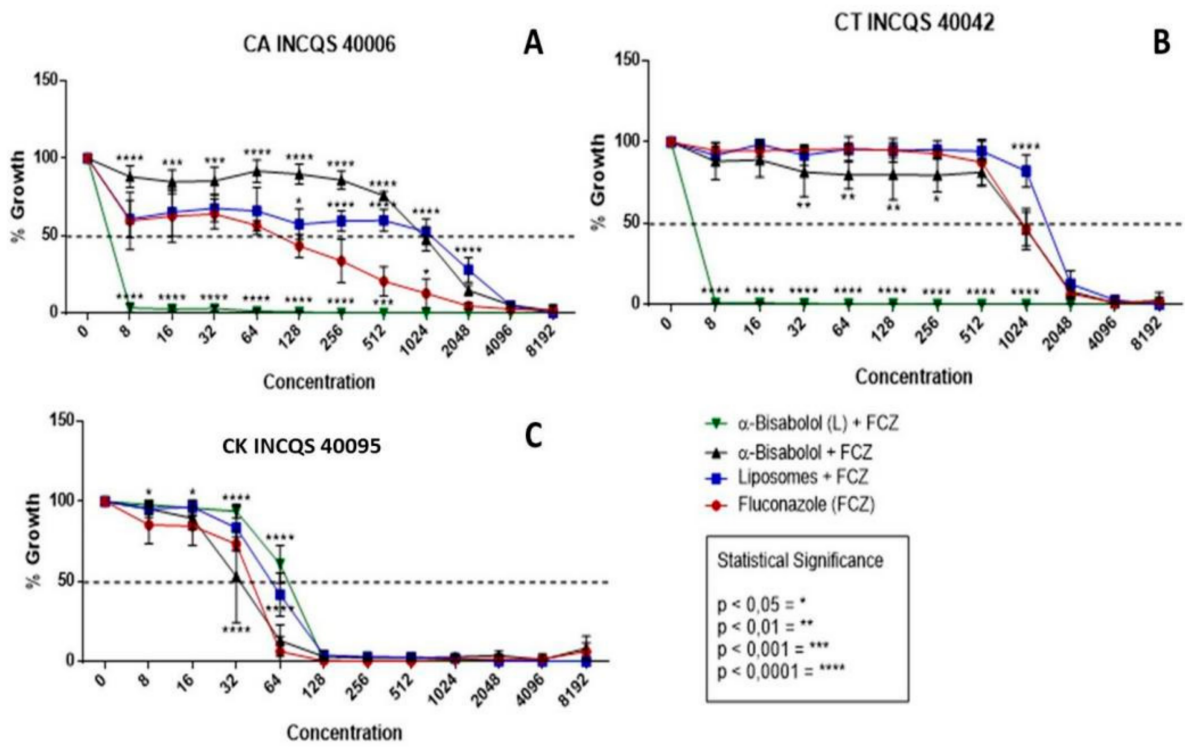

Figure 2. Cell viability curve $(\mu \mathrm{g} / \mathrm{mL})$ of free $\alpha$-bisabolol, $\alpha$-bisabolol in liposomal form, and liposomes (control) associated with fluconazole against Candida strains. (L): lipossomal; CA: Candida albicans; CT: Candida tropicalis; CK: Candida krusei INCQS: National Institute for Quality Control in Health.

In these graphs, the performance of the compounds together with fluconazole was significantly relevant against the strains of $C$. albicans and C. tropicalis (Figure 2A,B), demonstrating a synergistic effect, since they were able to inhibit $100 \%$ of the formation of colonies from $8 \mu \mathrm{g} / \mathrm{mL}$, respectively, and these concentrations are clinically relevant. However, against C. krusei, the performance was indifferent for the compounds tested.

A peculiar fact in these graphs is that the same $\alpha$-bisabolol product, without being in liposomal form, had an antagonistic effect against CA; however, by being linked to liposomes its effect is synergistic, which is to say that it presumably originated a liposomal compound of $\alpha$-bisabolol and fluconazole with a controlled and constant dispersion, causing possible damage to the membrane and preventing fungal growth. 


\subsection{Effect of the Compounds on Fungal Morphology}

Figure 3 shows the activity of the compounds on one of the fungal virulence factors, which is fungal dimorphism. The concentrations used were: Matrix Concentration (MC): 16,384 $\mu \mathrm{g} / \mathrm{mL}), \mathrm{MC} / 8: 2048 \mu \mathrm{g} / \mathrm{mL}$, and MC $/ 16: 1024 \mu \mathrm{g} / \mathrm{mL}$. From the data visualized in the graphs, it can be inferred that the action of fluconazole in preventing the formation of filamentous structures was significant in both concentrations and in all the tested strains because there was no growth at any time: thus, there was no presence of the yellow color indicative of fungal dimorphism in the presence of FCZ.

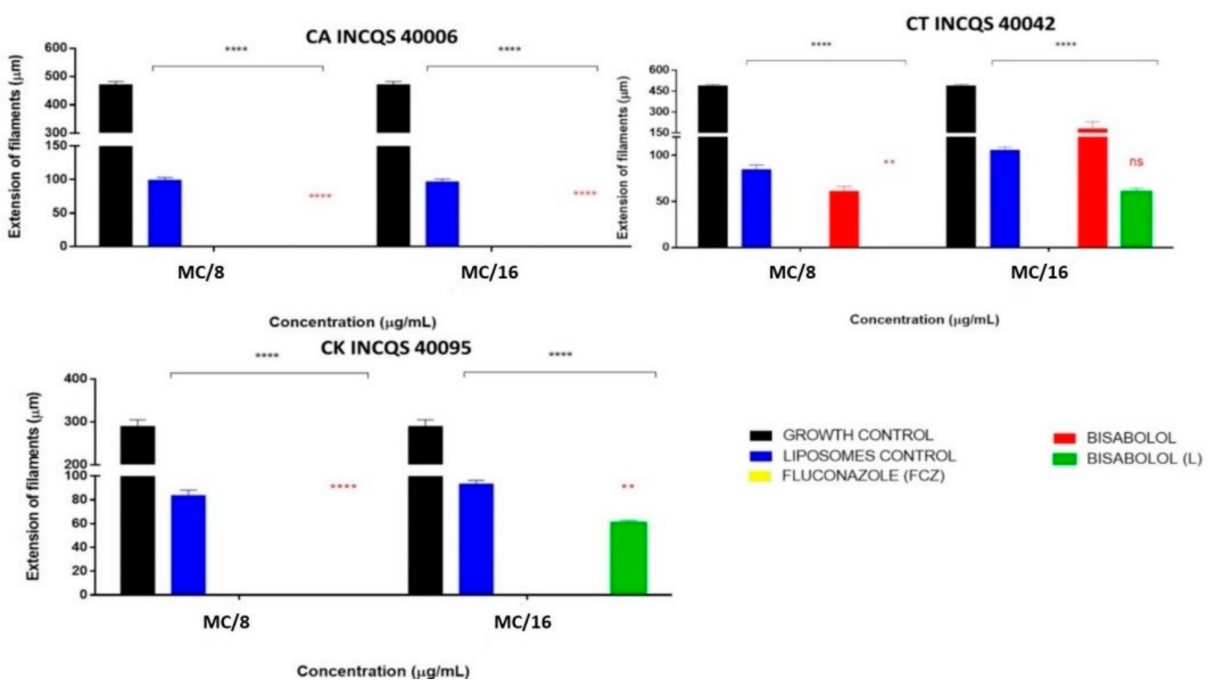

Figure 3. Effect of free $\alpha$-bisabolol, $\alpha$-bisabolol in liposomal form, liposomes (control) and isolated fluconazole (control) on fungal dimorphism against Candida strains. (L): liposomal; CA: Candida albicans; CT: Candida tropicalis; CK: Candida krusei; INCQS: National Institute for Quality Control in Health., FCZ: Fluconazole; Matrix Concentration (MC): 16,384 $\mu \mathrm{g} / \mathrm{mL}: \mathrm{MC} / 8: 2048 \mu \mathrm{g} / \mathrm{mL}$, and $\mathrm{MC} / 16: 1024 \mu \mathrm{g} / \mathrm{mL} .{ }^{*}$ in black indicates the significance of compounds compared to growth control; * in red indicates the significance of liposomal bisabolol compared to liposomal control.

The free and liposomal $\alpha$-bisabolol also managed to restrict $100 \%$ of the fungal dimorphism, in both concentrations, against $C$. albicans (Figure 3). Against CT, the isolated $\alpha$-bisabolol did not show a significant inhibitory effect. However, against the CK strain, it inhibited $100 \%$ of filamentous growth in both concentrations, this effect being statistically relevant. Moreover, this strain presents an intrinsic resistance to FCZ, this being an important result for the search for new antifungal compounds.

$\alpha$-bisabolol in liposomal form against CT and CK showed an important activity in its higher concentration, completely preventing fungal dimorphism in both strains; however, at the lower concentration, the effect against these strains was not significant.

\subsection{Vesicle Size, Polydispersity Index, and Average Zeta Potential}

Regarding the characterization of the tested liposomal compounds, it was caused by the dispersion of dynamic light, presenting spherical and homogeneous vesicles with significant dimensions, as expected. Table 2 shows average size diameters of $185.46 \mathrm{~nm}$ for the control of liposomes and $203.8 \mathrm{~nm}$ for liposomal $\alpha$-bisabolol. These data were expected due to the extrusion process having been carried out with filters with 200-nm membranes. The surface charge potential was identified from the Zeta, which reproduced the residual negative charge on the surface of the vesicles, thus ensuring a greater system stability and surface properties that could be modified in processes and formulations. 
Table 2. Characterization of liposomes' vesicular size, dispersivity ratio, and Zeta potential.

\begin{tabular}{cccc}
\hline Formulation & Size $(\mathbf{n m}) \pm \mathbf{S D}$ & PI \pm SD & Zeta Potential $(\mathbf{m V}) \pm$ SD \\
\hline Control of liposomes & $185.46 \pm 3.76$ & $0.48 \pm 0.01$ & $-40.9 \pm 0.96$ \\
\hline $\begin{array}{c}\text { liposomal } \\
\alpha \text {-bisabolol }\end{array}$ & $203.8 \pm 147.7$ & $0.52 \pm 0.04$ & $-34.2 \pm 0.91$ \\
\hline
\end{tabular}

Size (nm: nanometer) and the Zeta potential $(\mathrm{mV})$ of liposomal Bisabolol and control liposomes. Measurements were performed with diluted samples using water as a dispersion medium, at $25^{\circ} \mathrm{C}$. PI $=$ polydispersity index SD: standard deviation.

In Figure 4A, we have a scanning electron microscopy image where we visualize vesicles with a spherical shape and similar populations; next to it, in Figure 4B, we have a graph with data of the particle size by particle concentration per $\mathrm{mL}$. The controls used in the tests were the same contained in the work by Bezerra et al. [39].
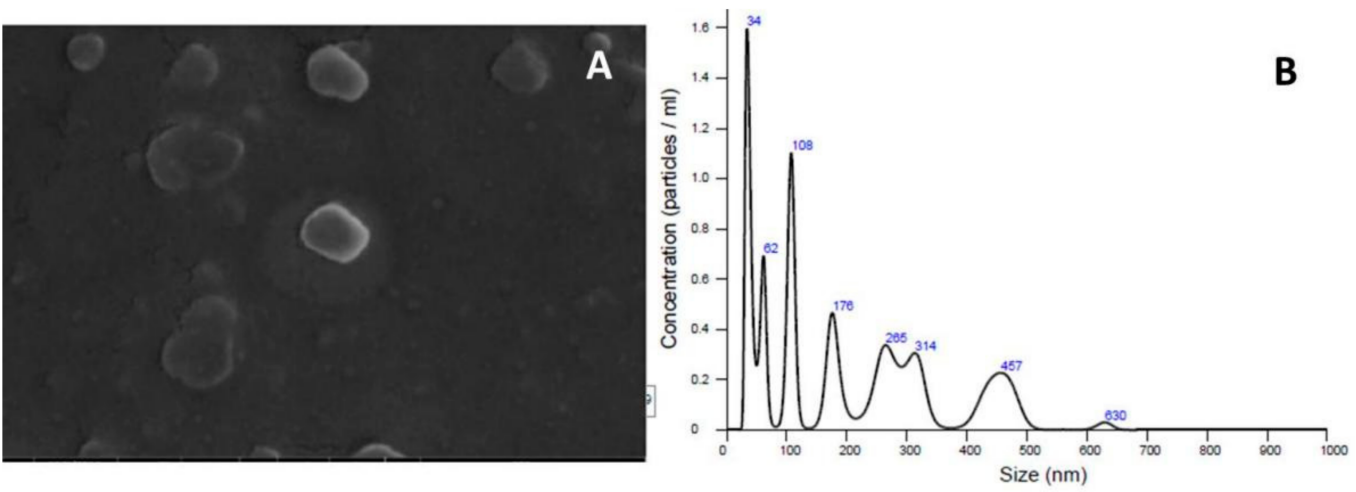

Figure 4. Example of a (A) scanning electron microscopy (SEM) image of liposomal $\alpha$-bisabolol and (B) the 251 graph of the vesicle size by particle concentration $/ \mathrm{mL}$.

\section{Discussion}

In the present study, the association of fluconazole with liposomal $\alpha$-bisabolol caused a potentiating effect of the controlled drug, demonstrating a considerable antifungal action; however, no similar research to refute the results found in this work was found in the literature.

The sesquiterpene highlighted in this work presents proven biological activities, such as anti-inflammatory, antispasmodic, and antimutagenic properties [40,41], as well as antimicrobial properties [42]. Characterized by being a natural phenylpropanoid, it exhibits low toxicity in biological systems and has been widely used in cosmetic industries [43]. Recently, many studies have shown antimicrobial effects of this compound [44-46].

In the current study, $\alpha$-bisabolol in liposomal form was able to inhibit the morphological transition from yeast to a filamentous invasive form; this activity has already been elucidated in previous research, which has revealed, in fungi and bacteria, the induction of apoptosis by bisabolol interacting with fungal hyphal membranes and deteriorating them [47].

Regarding the encapsulation of $\alpha$-bisabolol in liposomes, previous studies report that $\alpha$-bisabolol is one of the main compounds, and its encapsulation may be suitable for biomedical applications [48]. This mechanism of inhibition by induction of cell apoptosis, is characterized by reduced oxygen consumption in human and mouse glioma cells, due to changes in the structure and function of mitochondrial permeability at the transition pore [49].

Regarding the liposomal action, previous studies elucidated that the in vitro evaluation of liposomes containing the essential oil of Zanthoxylum tingoassuiba, which has $\alpha$-bisabolol as its major component, showed a significant antimicrobial activity by disk diffusion against gram-positive bacteria and dermatophyte fungi. Similar to the present study, liposomes loaded with the oil showed an adequate sphericity; however, in relation 
to the size, the result was discordant, since the carried liposomes were narrower than the empty liposomes [48].

Among the possibilities for the mechanism of action of $\alpha$-bisabolol against fungal cells, the study by Pauli [50] reports that $\alpha$-bisabolol extracted from Matricaria chamomilla has a potential fungal inhibitor due to the specific inhibition of ergosterol biosynthesis.

The antimicrobial effect of 20 essential oil constituents, including bisabolol, was evaluated using the broth microdilution method. Although bisabolol exhibited a weak activity against Staphylococcus aureus, Bacillus cereus, and Escherichia coli, the activity against C. albicans was significant and comparable to linalool (MIC values: 36 and $39 \mathrm{mM}$, respectively) [51].

The crude extract of Myrcia tomentosa (Aubl.) DC. leaves, $\alpha$-bisabolol being one of its major compounds, inhibited the in vitro growth of yeasts at concentrations of 4 to $32 \mu \mathrm{g} / \mathrm{mL}$. The hexane, dichloromethane, ethyl acetate, and aqueous fractions inhibited Candida sp. at concentrations from 4 to $256 \mu \mathrm{g} / \mathrm{mL}$ [52].

In the work by Galvão et al. [53], when testing bisabolol against Candida strains (the species of the present study), a significant antifungal effect of bisabol both on its own and associated with fluconazole with $\mathrm{IC}_{50}$ in low concentrations was observed, which is inconsistent with the present study regarding the action of the compound acting in isolation.

In the present study, liposomal and isolated bisabolol were able to inhibit fungal growth and hyphae formation (an important virulence factor) in the CA and CK strains, which may have occurred because bisabolol was able to alter the formation of ergosterol, an important structural component of the fungal membrane.

This fact can be justified with the study by Jahanshiri et al. [43], which, when testing $\alpha$-bisabolol against Aspergillus fumigatus, observed that there was a strong reduction in the synthesis of ergosterol (26.31-73.77\%) in addition to the suppression of the expression of the erg 6 gene (an important gene in the pathway of biosynthesis of the ergosterol) by $76.14 \%$, inhibiting the formation of hyphae.

\section{Conclusions}

In conclusion, the results showed an antifungal potential of $\alpha$-bisabolol in liposomal form, which acted as an antimicrobial against strains of C. albicans (CA) and C. tropicalis (CT) in microdilution tests, and that the liposomal $\alpha$-bisabolol form potentiated the effect of fluconazole acting with a modulating effect, with a statistically relevant action against CA and CT. Isolated $\alpha$-bisabolol combined with fluconazole reduced the effect of fluconazole against CA and CT strains. Under this perspective, the compound in liposomal form showed prominence by acting on fungal virulence, dimorphism, since it inhibited this mechanism in all strains that were tested at the concentration $\mathrm{MC} / 8$. In the second concentration, it obtained a significant effect against CA and CK, where it inhibited the formation of filamentous structures $(\mathrm{MC} / 16)$, and in $\mathrm{CT}$ the inhibition was indifferent. The liposomes had homogeneous populations, with small vesicles of $203.8 \mathrm{~nm}( \pm 147.7)$. The scanning microscopy results showed the spherical shape of the vesicles. Due to the pioneering work involving the antifungal activity of liposomal $\alpha$-bisabolol associated with fluconazole, additional research involving the molecular mechanisms of the inhibitory effects of $\alpha$-bisabolol and liposomes demonstrated here should be further investigated.

Author Contributions: C.F.B., R.d.L.H., A.T.L.d.S. and J.G.d.A.J. participated in all the essays and wrote all the sections, with emphasis on the formulation and characterization of the nanostructure; J.C.P.d.S., T.G.d.S. (Taís Gusmão da Silva), M.C.F.B. and J.P.V.R. helped describe the results of Cell Viability and Determination of the 50\%-IC50 Inhibitory Concentration and Antifungal SectionsLiposomal Bisabolol Improvement Activity in Combination with Fluconazole. T.A.T.V., D.L.S., J.M.B.F. and L.R.P. wrote and were part of the statistical analysis and revised the section Effects of Treatments on Fungal Morphology. T.S.d.F. performed the statistical analysis of the work. A.P.P., H.D.M.C., M.F.B.M.-B. and T.G.d.S. (Teresinha Gonçalves da Silva) revised and completely complemented the draft of the manuscript. All authors contributed to the summary, conclusion, and 
corrections suggested by the reviewers. All authors read and agreed with the published version of the manuscript.

Funding: There was no research funding.

Institutional Review Board Statement: Not applicable.

Informed Consent Statement: Not applicable.

Acknowledgments: We thank the National Council for Scientific Development and Technological (CNPq) and the Coordination for the Improvement of Level Personnel Superior (CAPES) for supporting the work.

Conflicts of Interest: The authors declare no conflict of interest.

\section{References}

1. Kristan, K.; Rižner, T.L. Steroid-transforming enzymes in fungi. J. Steroid Biochem. Mol. Biol. 2012, 129, 79-91. [CrossRef]

2. Pendleton, K.M.; Huffnagle, G.B.; Dickson, R.P. The significance of Candida in the human respiratory tract: Our evolving understanding. Pathog. Dis. 2017, 75, ftx029. [CrossRef]

3. Kullberg, B.J.; Arendrup, M.C. Invasive Candidiasis. N. Engl. J. Med. 2015, 373, 1445-1456. [CrossRef]

4. Magill, S.S.; Edwards, J.R.; Bamberg, W.; Beldavs, Z.G.; Dumyati, G.; Kainer, M.A.; Lynfield, R.; Maloney, M.; McAllis-ter-Hollod, L.; Nadle, J.; et al. Multistate Point-Prevalence Survey of Health Care-Associated Infections. N. Engl. J. Med. 2014, 370, $1198-1208$. [CrossRef]

5. McCarty, T.P.; Pappas, P.G. Invasive Candidiasis. Infect. Dis. Clin. 2016, 30, 103-124. [CrossRef]

6. Pappas, P.G.; Rex, J.H.; Lee, J.; Hamill, R.J.; Larsen, R.A.; Powderly, W.; Kauffman, C.A.; Hyslop, N.; Mangino, J.E.; Chapman, S.; et al. A Prospective Observational Study of Candidemia: Epidemiology, Therapy, and Influences on Mortality in Hospitalized Adult and Pediatric Patients. Clin. Infect. Dis. 2003, 37, 634-643. [CrossRef]

7. Wisplinghoff, H.; Bischoff, T.; Tallent, S.M.; Seifert, H.; Wenzel, R.P.; Edmond, M.B. Nosocomial Bloodstream Infections in US Hospitals: Analysis of 24,179 Cases from a Prospective Nationwide Surveillance Study. Clin. Infect. Dis. $2004,39,309-317$. [CrossRef]

8. Lo, H.-J.; Köhler, J.R.; DiDomenico, B.; Loebenberg, D.; Cacciapuoti, A.; Fink, G.R. Nonfilamentous C. albicans Mutants Are Avirulent. Cell 1997, 90, 939-949. [CrossRef]

9. Murad, A.A.; Leng, P.; Straffon, M.; Wishart, J.; Macaskill, S.; Maccallum, D.M.; Schnell, N.; Talibi, D.; Marechal, D.; Tekaia, F.; et al. NRG1 represses yeast-hypha morphogenesis and hypha-specific gene expression in Candida albicans. EMBO J. 2001, 20, 4742-4752. [CrossRef]

10. Pappas, P.G.; Lionakis, M.S.; Arendrup, M.C.; Ostrosky-Zeichner, L.; Kullberg, B.J. Invasive candidiasis. Nat. Rev. Dis. Prim. 2018, 4, 18026. [CrossRef]

11. Sikkema, J.; Bont, J.A.M.; Poolman, B. Mechanisms of membrane toxicity of hydrocarbons. Microbiol. Rev. 1995, 59, $201-222$. [CrossRef]

12. Burt, S. Essential oils: Their antibacterial properties and potential applications in foods-A review. Int. J. Food Microbiol. 2004, 94, 223-253. [CrossRef] [PubMed]

13. Morales-Yuste, M.; Morillas-Márquez, F.; Martín-Sánchez, J.; Valero-López, A.; Navarro-Moll, M. Activity of (-) $\alpha$-bisabolol against Leishmania infantum promastigotes. Phytomedicine 2010, 17, 279-281. [CrossRef]

14. Tabanca, N.; Demirci, B.; Crockett, S.L.; Başer, K.H.C.; Wedge, D.E. Chemical composition and antifungal activity of Arnica longifolia, Aster hesperius, and Chrysothamnus nauseosus essential oils. J. Agric. Food Chem. 2007, 55, 8430-8435. [CrossRef] [PubMed]

15. Leite, G.D.O.; Ecker, A.; Seeger, R.L.; Krum, B.N.; Lugokenski, T.H.; Fachinetto, R.; Sudati, J.H.; Barbosa, N.V.; Wagner, C. Protective effect of $(-)-\alpha$-bisabolol on rotenone-induced toxicity in Drosophila melanogaster. Can. J. Physiol. Pharmacol. 2018, 96, 359-365. [CrossRef] [PubMed]

16. Almeida, P.F. Thermodynamics of lipid interactions in complex bilayers. Biochim. Biophys. Acta Biomembr. 2009, 1788, 72-85. [CrossRef]

17. Róg, T.; Pasenkiewicz-Gierula, M.; Vattulainen, I.; Karttunen, M. Ordering effects of cholesterol and its analogues. Biochim. Biophys. Acta Biomembr. 2009, 1788, 97-121. [CrossRef]

18. Bouaoud, C.; Lebouille, J.G.J.L.; Mendes, E.; De Braal, H.E.A.; Meesters, G.M.H. Formulation and antifungal performance of natamycin-loaded liposomal suspensions: The benefits of sterol-enrichment. J. Liposome Res. 2015, 26, 103-112. [CrossRef]

19. Schiffelers, R.M.; A A Kooijmans, S.; Vader, P.; van Dommelen, S.M.; van Solinge, W.W. Exosome mimetics: A novel class of drug delivery systems. Int. J. Nanomed. 2012, 7, 1525-1541. [CrossRef]

20. Ha, D.; Yang, N.; Nadithe, V. Exosomes as therapeutic drug carriers and delivery vehicles across biological membranes: Current perspectives and future challenges. Acta Pharm. Sin. B 2016, 6, 287-296. [CrossRef]

21. Ragusa, M.; Barbagallo, D.; Purrello, M.; Barbagallo, D. Exosomes: Nanoshuttles to the future of BioMedicine. Cell Cycle 2015, 14, 289-290. [CrossRef] 
22. Ambati, S.; Ellis, E.C.; Lin, J.; Lin, X.; Lewis, Z.A.; Meagher, R.B. Dectin-2-targeted antifungal liposomes exhibit enhanced efficacy. Msphere 2019. [CrossRef]

23. Song, Y.K.; Liu, F.; Chu, S.; Liu, D. Characterization of Cationic Liposome-Mediated Gene Transfer In Vivo by Intravenous Administration. Hum. Gene Ther. 1997, 8, 1585-1594. [CrossRef]

24. Kamimura, K.; Liu, D. Physical Approaches for Nucleic Acid Delivery to Liver. AAPS J. 2008, 10, 589-595. [CrossRef]

25. Barua, S.; Mitragotri, S. Challenges associated with penetration of nanoparticles across cell and tissue barriers: A review of current status and future prospects. Nano Today 2014, 9, 223-243. [CrossRef] [PubMed]

26. Yuan, F.; Leunig, M.; Huang, S.K.; Berk, D.A.; Papahadjopoulos, D.; Jain, R.K. Mirovascular permeability and interstitial penetration of sterically stabilized (stealth) liposomes in a human tumor xenograft. Cancer Res. 1994, 54, 3352-3356. [PubMed]

27. Hector, R.F.; Braun, P.C. Synergistic action of nikkomycins $X$ and $Z$ with papulacandin $B$ on whole cells and regenerating protoplasts of Candida albicans. Antimicrob. Agents Chemother. 1986, 29, 389-394. [CrossRef]

28. Aprovada, N. Método de Referência para Testes de Diluicão em Caldo para Determinacão da Sensibilidade à Terapia Antifúngica das leveduras, Norma Aprovada; NCCLS Norma M27-A2, 2nd ed.; NCCLS: Wayne, PA, USA, 2002; pp. 19087-19898. ISBN 1-56238-469-4.

29. Stoppa, M.A.; Casemiro, L.A.; Vinholis, A.H.C.; Cunha, W.R.; Silva, M.L.A.; Martins, C.H.G.; Furtado, N.A.J.C. Estudo comparativo entre as metodologias preconizadas pelo CLSI e pelo EUCAST para avaliação da atividade antifúngica. Química Nova 2009, 32, 498-502. [CrossRef]

30. Javadpour, M.M.; Juban, M.M.; Lo, W.C.J.; Bishop, S.M.; Alberty, J.B.; Cowell, S.M.; Becker, C.L.; McLaughlin, M.L. De novo antimicrobial peptides with low mammalian cell toxicity. J. Med. Chem. 1996, 39, 3107-3113. [CrossRef] [PubMed]

31. Morais-Braga, M.F.B.; Sales, D.L.; Carneiro, J.N.P.; Machado, A.J.T.; Dos Santos, A.T.L.; de Freitas, M.A.; Martins, G.M.D.A.B.; Leite, N.F.; de Matos, Y.M.L. Psidium guajava L. and Psidium brownianum Mart ex DC.: Chemical composition and anti-Candida effect in association with fluconazole. Microb. Pathog. 2016, 95, 200-207. [CrossRef]

32. Ernst, E.J.; E Klepser, M.; E Ernst, M.; A Messer, S.; A Pfaller, M. In vitro pharmacodynamic properties of MK-0991 determined by time-kill methods. Diagn. Microbiol. Infect. Dis. 1999, 33, 75-80. [CrossRef]

33. Coutinho, H.D.; Costa, J.G.; Lima, E.O.; Falcão-Silva, V.S.; Siqueira-Júnior, J.P. Enhancement of the Antibiotic Activity against a Multiresistant Escherichia coli by Mentha arvensis L. and Chlorpromazine. Chemotherapy 2008, 54, 328-330. [CrossRef]

34. Sidrin, J.J.C.; Rocha, M.F.G. Micologia Médica à Luz de Autores Contemporâneos; Guanabara Koogan: Rio de Janeiro, Brazil, 2010; p. 388.

35. Mendes, J.M. Investigação da Atividade Antifúngica do Óleo Essencial de Eugenia caryophyllata Thunb. Sobre Cepas de Candida tropicalis. Master's Thesis, Federal University of Paraiba, João Pessoa, Brazil, 2011.

36. Carneiro, J.N.P.; da Cruz, R.P.; da Silva, J.C.P.; Rocha, J.E.; de Freitas, T.S.; Sales, D.L.; Bezerra, C.F.; de Oliveira Almeida, W.; da Costa, J.G.M.; da Silva, L.E.; et al. Piper diospyrifolium Kunth.: Chemical analysis and antimicrobial (intrinsic and combined) activities. Microb. Pathog. 2019, 136, 103700. [CrossRef] [PubMed]

37. Barros, N.B.; Migliaccio, V.; Facundo, V.A.; Ciancaglini, P.; Stábeli, R.G.; Nicolete, R.; Silva-Jardim, I. Liposomal-lupane system as alternative chemotherapy against cutaneous leishmaniasis: Macrophage as target cell. Exp. Parasitol. 2013, 135, 337-343. [CrossRef] [PubMed]

38. Júnior, J.G.D.A.S.; Freitas, P.R.; Rocha, J.E.; Pereira, R.L.S.; Tintino, C.D.D.M.O.; Gonçalves, V.P.; Rodrigues, J.P.V.; Coutinho, H.D.M.; Nicolete, R. Intrinsic modifying-antibiotic activity of a liposomal structure against MRSA and other MDR bacteria. Biocatal. Agric. Biotechnol. 2021, 31, 101880.

39. Bezerra, C.F.; de Alencar Júnior, J.G.; de Lima Honorato, R.; Dos Santos, A.T.L.; da Silva, J.C.P.; da Silva, T.G.; Leal, A.L.A.B.; Rocha, J.E.; de Freitas, T.S.; Vieira, T.A.T.; et al. Antifungal activity of farnesol incorporated in liposomes and associated with fluconazole. Chem. Phys. Lipids 2020, 233, 104987. [CrossRef]

40. Holub, M.; Herout, V.; Sorm, F. Synthesis of alpha-bisabolol-A spasmolytically active sequiterpenic alcohol. Ceskoslovenska Farm. 1955, 4, 129.

41. Gomes-Carneiro, M.R.; Dias, D.M.; de-Oliveira, A.C.A.X.; Paumgartten, F.J. Evaluation of mutagenic and antimutagenic activities of $\alpha$-bisabolol in the Salmonella/microsome assay. Mutat. Res. Genet. Toxicol. Environ. Mutagenes. 2005, 585, 105-112. [CrossRef] [PubMed]

42. Pauli, A.; Schilcher, H. Infektionen, Entzündungen, Wunden: 18 Fallbeispiele zu (-)-alpha-Bisabolol. Komplementäre Integr. Med. 2009, 50, 28-32. [CrossRef]

43. Jahanshiri, Z.; Shams-Ghahfarokhi, M.; Asghari-Paskiabi, F.; Saghiri, R.; Razzaghi-Abyaneh, M. $\alpha$-Bisabolol inhibits Aspergillus fumigatus Af239 growth via affecting microsomal $\Delta 24$-sterol methyltransferase as a crucial enzyme in ergosterol biosynthesis pathway. World J. Microbiol. Biotechnol. 2017, 33, 55. [CrossRef]

44. Tolouee, M.; Alinezhad, S.; Saberi, R.; Eslamifar, A.; Zad, S.J.; Jaimand, K.; Taeb, J.; Rezaee, M.-B.; Kawachi, M.; ShamsGhahfarokhi, M.; et al. Effect of Matricaria chamomilla L. flower essential oil on the growth and ultrastructure of Aspergillus niger van Tieghem. Int. J. Food Microbiol. 2010, 139, 127-133. [CrossRef]

45. Forrer, M.; Kulik, E.M.; Filippi, A.; Waltimo, T. The antimicrobial activity of alpha-bisabolol and tea tree oil against Solobacterium moorei, a Gram-positive bacterium associated with halitosis. Arch. Oral Biol. 2013, 58, 10-16. [CrossRef]

46. Romagnoli, C.; Baldisserotto, A.; Malisardi, G.; Vicentini, C.B.; Mares, D.; Andreotti, E.; Vertuani, S.; Manfredini, S. A MultiTarget Approach toward the Development of Novel Candidates for Antidermatophytic Activity: Ultrastructural Evidence on $\alpha$-Bisabolol-Treated Microsporum gypseum. Molecules 2015, 20, 11765-11776. [CrossRef] 
47. De Lucca, A.J.; Pauli, A.; Schilcher, H.; Sien, T.; Bhatnagar, D.; Walsh, T.J. Fungicidal and Bactericidal Properties of Bisabolol and Dragosantol. J. Essent. Oil Res. 2011, 23, 47-54. [CrossRef]

48. Detoni, C.B.; Cabral-Albuquerque, E.C.M.; Hohlemweger, S.V.A.; Sampaio, C.; Barros, T.F.; Velozo, E.S. Essential oil from Zanthoxylum tingoassuiba loaded into multilamellar liposomes useful as antimicrobial agents. J. Microencapsul. 2009, 26, 684-691. [CrossRef] [PubMed]

49. Cavalieri, E.; Bergamini, C.; Mariotto, S.; Leoni, S.; Perbellini, L.; Darra, E.; Suzuki, H.; Fato, R.; Lenaz, G. Involvement of mitochondrial permeability transition pore opening in $\alpha$-bisabolol induced apoptosis. FEBS J. 2009, 276, 3990-4000. [CrossRef]

50. Pauli, A. $\alpha$-Bisabolol from chamomile-a specific ergosterol biosynthesis inhibitor. Int. J. Aromather. 2006, 16, 21-25. [CrossRef]

51. Van Zyl, R.L.; Seatlholo, S.T.; van Vuuren, S.F.; Viljoen, A.M. The biological activities of 20 nature identical essential oil constituents. J. Essent. Oil Res. 2006, 18, 129-133. [CrossRef]

52. Sa, F.A.D.S.; De Paula, J.A.M.; Dos Santos, P.A.; Oliveira, L.D.A.R.; Oliveira, G.D.A.R.; Liao, L.M.; De Paula, J.R.; Silva, M.D.R.R. Phytochemical Analysis and Antimicrobial Activity of Myrcia tomentosa (Aubl.) DC. Leaves. Molecules 2017, $22,1100$.

53. Rodrigues, F.F.G.; Colares, A.V.; Nonato, C.D.F.A.; Galvão-Rodrigues, F.F.; Mota, M.L.; Braga, M.F.B.M.; da Costa, J.G.M. In vitro antimicrobial activity of the essential oil from Vanillosmopsis arborea Barker (Asteraceae) and its major constituent, $\alpha$-bisabolol. Microb. Pathog. 2018, 125, 144-149. [CrossRef] [PubMed] 